Yearbook of the Universities of the Commonwealth

Thirty-third Issue. Pp. lix +1925. (London: Association of Universities of the British Commonwealth, 1956.) 63s.

7 HIs useful handbook has been steadily growing in size with each new edition, that for last year being just over two thousand pages. If the new material that has accumulated since then had been incorporated without any adjustment of the existing contents, the present work would probably have been a hundred or more pages longer, and the volume would have been in danger of becoming unwieldya fault the magnitude of which is in direct proportion to the frequency with which the book is consulted.

Fortunately, the editor has taken steps to rectify this and, by a slight reduction in the contents, has managed to make this year's edition about a hundred pages shorter than the previous one. The three appendixes in the 1955 edition on postgraduate awards, Anglo-American academic relations and international university organizations, respectively, have been omitted, although the first one is available as a separate pamphlet. In the entry for each university headed "The Year", there are no longer the paragraphs on principal changes in regulations, adult education work, and visits by teachers; furthermore, those on benefactions, new buildings, and new departments and posts have been pruned.

This lopping, not of dead wood, but of branches that were not over-fruitful, has made room for some new growths-notably a new appendix on British academic institutions abroad, and an analysis, in many of the separate university entries, of the distribution of students by faculties. The new appendix covers three institutions: the British Institute in Paris ; the British School at Rome; and the British School of Archæology at Athens. Thus it will be seen that the "Universities Yearbook", as it used to be entitled and is still commonly referred to, is very much alive and is likely to flourish for many a year to come.

The Birds of the British Isles

By Dr. David Armitage Bannerman. Vol. 5: Fal. conidae, Accipitridae, Aegypiidae, Pandionidae. Pp. xiii $+350+34$ plates. (Edinburgh and London: Oliver and Boyd, Ltd., 1956.) 63s. net.

WTITH this fifth volume, Dr. D. A. Bannerman's scholarly survey of knowledge of British birds nears the half-way mark. There is here interpolated a brief memoir and a portrait of George Edward Lodge, the author's artist partner who died after the work had begun to appear. This tribute could not have been more fittingly placed, because his artistry was at its very best when birdsof-prey were his subjects; and within the $\operatorname{sam} \theta$ covers we have many outstanding examples of his work-incidentally, in several instances more than one plate of a single species, illustrating geographical or developmental differences in plumage.

The whole volume is devoted to the four families of diurnal birds-of-prey-falcons, hawks (in the widest sense), vultures and osprey; and that there are only some two dozen species will give an idea of the extent and detail of the treatment. The author quotes freely from others; but some of their material has not been published before and he has often facts to add from his own observations. Nowhere else would one find together so much information about the migrations and habits of each species, based on study at home and abroad. In respect of this group there is a wealth of observation of spectacular passages in some parts of the world ; and the variety of hunting habits is of much interest, including the aerial 'pass' of food from the male to his mate exemplified by Montagu's harrier and by the hobby. The account of British status is too often a sad story of dwindling numbers and of a lost or precarious foothold. The use of certain species in falconry, once "the sport of kings", receives due mention.

Landsborough Thomson

\section{The Number System}

By Dr. H. A. Thurston. Pp. viii +134. (London and Glasgow : Blackie and Son, Ltd., 1956.) 15s. net.

$\mathrm{D}$ R. H. A. THURSTON has two aims in view : he wishes to explain to the intelligent nonmathematician the way in which the number-field is extended from the integers through the rationals to the irrationals and the field of complex numbers; he also wishes to give the student of mathematics a complete logical account of these extensions. He has therefore divided his book into two parts : the first half is a semi-popular discussion of the way in which needs to extend the number system have arisen and have been met, a broad and interesting general survey from which details have been omitted; the second half, similar to Landau's "Grundlagen der Analysis", gives the austere logical development, from the integers founded on Peano's axioms to the rationals as ordered pairs of integers, the irrationals as Cauchy sequences of rationals, and the complex numbers as ordered pairs of real numbers. But the two parts. are closely interwoven; serious readers of the first part will surely wish to see a portion at least of the detailed working-out of general principles, while the young student will grasp the occasional logical twists of the second part more readily if he makes constant reference back to the more discursive explanations of the first part. The author has taken great pains with both parts, and does not appear to have fallen. between two stools. T. A. A. Broadbent

\section{Grignard Reactions of Nonmetallic Substances}

By Prof. M. S. Kharasch and Otto Reinmuth. Pp. xxii +1384. (New York: Prentice-Hall, Inc.; London : Constable and Co., Ltd., 1954.) 135s. net.

7 HE Grignard reaction is now a major method in organic chemistry. The range of its application. is very extensive, and it has an enormous literature. A real service has been rendered in the preparation. of this book.

It is by no means a bare catalogue of reactions and a bibliography, although it includes both. It contains readable statements of the underlying chemistry, brief historical surveys, and (what is valuable) new suggestions on possible reaction mechanisms. Particular attention is given to grouping reactions so as to facilitate reference, and the literature references are very complete. In the case of Russian and Japanese papers, references to Chemical Abstracts are also given. The 'normal' reactions are defined in each case, and deviations from them are explained.

The volume is an outstanding contribution to chemical literature which should be available in every organic chemical laboratory, where it is likely to be in daily use. Although the price is high, the book is worth it. 